\title{
A Study of Outcome of Perinatal Asphyxia in a Tertiary Care Hospital
}

\author{
Jyotiranjan Champatiray, Kedarnath Das, Mangal Charan Murmu
}

Associate Professor, Department of Paediatrics, S C B Medical College, Cuttack, Odisha, India

DOI: $10.36347 /$ sjams.2020.v08i06.017

| Received: 07.06.2020 | Accepted: 15.06.2020 | Published: 20.06.2020

*Corresponding author: Mangal Charan Murmu

Abstract

Original Research Article

Introduction: Birth asphyxia is one of the common cause of mortality and morbidity in neonate and the incidence is 2 9 per 1000 live born. Perinatal asphyxia is an important cause of mortality and of subsequent neurologic disabilities among the infants who survive. Aim \& objective: To study the incidence of mortality \& morbidity in birth asphyxia. Material \& Method: The study was conducted in the Obstetrics department, Special Newborn Care Unit (SNCU)/Pediatrics, District Early Intervention Centre (DEIC), department of SVP PG I P \& S C B Medical College, Cuttack after obtaining clearance from institutional ethical committee. The study was conducted from January 2018 to December 2019. The study was a prospective study. Result: Severe HIE (stage-III) was associated with a grave prognosis. Mortality was very high. Survivors had gross developmental delay and severe neurological deficits. Poor growth pattern was noted in HIE - II and HIE-III. Conclusion: Perintal asphyxia is preventable condition. Timely and corrective step taken during the each and every step during the delivery process will definitely reduce the incidence of perinatal asphyxia \& there by reducing the number of encephalopathy, also reduces the burdens of mortality and morbidity.

Keywords: Perinatal asphyxia, Neurological outcome, Hypoxic-Ischemic Encephalopathy, Neonatal mortality.

Copyright @ 2020: This is an open-access article distributed under the terms of the Creative Commons Attribution license which permits unrestricted use, distribution, and reproduction in any medium for non-commercial use (NonCommercial, or CC-BY-NC) provided the original author and source are credited.

\section{INTRODUCTION}

Each newborn has the right to live in good health without handicap and each death should count to prevent others. Neonatal perinatal data base collects information regarding the risk factors profile of neonatal morbidity \& mortality. According to NNPD 2010 report that most common cause of neonatal death was perinatal asphyxia $54.9 \%$, followed by extreme prematurity $28.6 \%$, congenital malformation $4.5 \%$, sepsis $4.1 \%[1]$. Globally hypoxia of newborn (birth asphyxia) is estimated to account for $23 \%$ of the four million death and $26 \%$ of the 3.2 million still births each year [2-4]. An estimated 1 million children who survive birth asphyxia live with chronic neurodevelopmental morbidities, including cerebral palsy, mental retardation, and learning disabilities [5].

Birth asphyxia is defined by the World Health Organization as "the failure to initiate and sustain breathing at birth [6]. Definitions of birth asphyxia designed for use in hospital-based settings require evaluation of neonatal umbilical cord $\mathrm{pH}$, Apgar scores (Appearance, Pulse, Grimace, Activity, and Respiration), neurological clinical status, and markers of multi-system organ function [7], and are not feasible for community settings[8]. National Neonatology
Forum of India has defined birth asphyxia as "gasping and ineffective breathing or lack of breathing at one minute after birth [9]. Birth asphyxia can be caused by events in the antepartum, the intrapartum or the postpartum periods or combinations of all three [10]. Clinical epidemiological studies also show that in most cases, the events leading to cerebral palsy occur in the fetus before the onset of labour or in the newborn after delivery [11]. Different sociodemgraphic, maternal and neonatal predisposing factors responsible for axphyxia neonatarum [12].

According to national neonatal perinatal data base (NPPD)2003 [13] and Thora S et al[14] ,found that neonatal sepsis was the most common cause of death in rural India followed by asphyxia and prematurity. Similar study Bhandari et al. [15] demonstrated that sepsis contributed to $45 \%$ of neonatal mortality, asphyxia to $25 \%$ and prematurity to $25 \%$ of mortality. Contradictory to the above study by Kapoor et al. [16] asphyxia was the most common cause of the death accounting for $42 \%$ followed by prematurity of $14 \%$ and sepsis of $12.3 \%$.

Neonatal encephalopathy is clinically defined as syndrome of disturbed neurological function in the earliest days of life in the term infant, manifested by 
difficulty with initiating and maintaining respiration, depression of tone and reflexes, sub normal level of consciousness and often by seizures [17]. In 1976, Sarnat and Sarnat described the Apgar score for defining neonatal encephalopathy [18].

In one study outcome was analysed according to Sarnat's stages of severity. Virtually $100 \%$ of new borns with mild encephalopathy had normal neurological outcome. $80 \%$ of those with encephalopathy were normal neurologically and virtually all children with severe encephalopathy died, $50 \%$ developed major neurologic sequlae like cerebral palsy (CP), mental retardation, epilepsy and micro encephalopathy (Zohn P. Cloherty).

Hypoxic-ischemic encephalopathy (HIE) is an important source of permanent damage to central nervous system tissues that may result in neonatal death or manifest later as cerebral palsy or developmental delay. In fact, about $20 \%-30 \%$ of infants with HIE die in the neonatal period, and $33 \%-50 \%$ of survivors are left with permanent neurodevelopmental abnormalities such as cerebral palsy and mental retardation [19].

The considerable medical, familial, social and legal ramifications of perinatal hypoxic-ischaemic encephalopathy (HIE) in term or late preterm newborns (NBs) make it a significant public health and social problem [20]

The evaluation of long-term outcome is stalled by the lack of a consensus on standard case definitions of birth asphyxia, difficulties in assessing asphyxia in non-hospital births and in measuring disabilities, especially among young children and the difficulty of attributing aetiology in the wake of malnutrition and disease [21].

Birth asphyxia is one of the common cause of mortality and morbidity in neonate and the incidence is 2-9 per 1000 live borns[22]. Perinatal asphyxia is an important cause of mortality and of subsequent neurologicdisabilities among the infants who survive [23].

Hence a study was planned to know the mortality and morbidity of birth asphyxia that were being treated and followed up in our institution.

\section{Aim and Objective}

To study the incidence of mortality \& morbidity in birth asphyxia.

\section{Material}

The study was conducted in the Obstetrics
department, Special Newborn Care Unit
(SNCU)/Paediatrics, District Early Intervention Centre (DEIC), department of SVP PG I P \& S C B Medical College, Cuttack after obtaining clearance from institutional ethical committee. The study was conducted from January 2018 to December 2019. After explaining the nature of study, the written consent from the parents was taken who were willing to include in the study. 151 newborn were selected for study by system random sampling method.

\section{Inclusion criteria}

Study cohort consist of hospitalized neonates in indoor of SCB MCH and SVP PG I P, Cuttack with diagnosis of birth asphyxia as per defined criteria, that is failure to start regular respiration within first one minute of birth.

\section{Exclusion criteria:}

1. Babies having congenital anomalies,

2. Syndromic babies,

\section{VLBW Babies}

The study was a prospective study.

\section{METHOD}

Neonates presenting with birth asphyxia were studied according to pre structured proforma together with the results of physical examination at the time of admission. Necessary investigation done to asses various complications, a careful record of the progress in the hospital was maintained to determine outcome in reference to neonatal mortality and handicap as done in follow up clinic.

\section{Plan of work}

General examination and detail neurological examination was carried out on all asphyxiated babies on admission. Thereafter daily examination was carried out at 24 hours interval till the baby gets discharged from the hospital or unfortunately die.

\section{Follow up}

The study was done on all babies who were discharged. For the first 6 months the children were called at one month interval and there after every two months interval for the rest six month.

\section{Statistical method}

The result was computed from the data obtained. The data analysed with respect to standard statistical methods. The data were noted in tabulate form, necessary statistical procedure was applied to observe the percentage outcome variable in different demoghraphic subgroups and other parametric and nonparametric analysis. Hypothesis verification was done as per necessity to arrive at conclusion. 


\section{Observation}

Table-1: Mode of delivery in relation to birth asphyxia

\begin{tabular}{|c|c|c|c|c|}
\hline Mode of delivery & No of birth asphyxia & Degree of birth asphyxia & Number & percentage \\
\hline \multirow[t]{3}{*}{ Normal delivery } & \multirow[t]{3}{*}{$75(43.0 \%)$} & Mild & 49 & 65.3 \\
\hline & & Moderate & 25 & 30.6 \\
\hline & & Severe & 3 & 4 \\
\hline \multirow[t]{3}{*}{ Breech } & \multirow[t]{3}{*}{$25(16.5 \%)$} & Mild & 7 & 28 \\
\hline & & Moderate & 14 & 56 \\
\hline & & Severe & 4 & 16 \\
\hline \multirow[t]{3}{*}{ Face } & \multirow[t]{3}{*}{$7(13.2 \%)$} & Mild & - & - \\
\hline & & Moderate & 1 & 14.2 \\
\hline & & Severe & 6 & 85.7 \\
\hline \multirow{3}{*}{$\begin{array}{l}\text { LSCS (lower segment } \\
\text { caesarean section) }\end{array}$} & \multirow[t]{3}{*}{$44(29.1 \%)$} & Mild & 28 & 63.6 \\
\hline & & Moderate & 7 & 15.9 \\
\hline & & Severe & 3 & 6.8 \\
\hline
\end{tabular}

The occurrence of severe degree of asphyxia is highest in face presentation $(85.7 \%)$ followed by $16 \%$ in breech presentation and $4 \%$ in normal delivery. The difference observed in the occurrence of severe degree of asphyxia among different mode of delivery was found to be statistically significant $(\mathrm{p}<0.05)$.

Table-2: Degree of birth asphyxia in relation to moratality

\begin{tabular}{|l|l|l|l|l|}
\hline Degree of asphyxia & No of asphyxia & Mortality & Cured without sequlae & Cured with sequlae \\
\hline Mild & $87(57.6 \%)$ & $5(5.74 \%)$ & $79(90 \%)$ & $3(3.4 \%)$ \\
\hline Moderate & $41(27.15 \%)$ & $7(17.0 \%)$ & $23(56 \%)$ & $8(19.5 \%)$ \\
\hline Severe & $23(15.23 \%)$ & $11(47.8 \%)$ & - & $8(100 \%)$ \\
\hline
\end{tabular}

Excluding 7 cases who got LAMA (left against medical advice), the cure rate was highest in mild asphyxia group (90\%) followed by $56 \%$ in moderate group and the difference was statistically significance $(p<0.05)$.similarly the mortality was highest in severe group $(\mathrm{p}<0.05)$.

Table-3: Place of delivery in relation to birth asphyxia

\begin{tabular}{|l|l|l|l|}
\hline \multicolumn{2}{|l|}{ Place of delivery } & No of birth asphyxia & Mortality \\
\hline \multirow{3}{*}{ Home } & Mild & $65(73.5 \%)$ & \multirow{1}{*}{$19(82.6 \%)$} \\
\cline { 2 - 3 } & Moderate & $31(73.2 \%)$ & \\
\cline { 2 - 3 } & Severe & $11(84.6 \%)$ & \\
\hline \multirow{3}{*}{ Hospital } & Mild & $32(34.4 \%)$ & \\
\cline { 2 - 3 } & Moderate & $10(26.8 \%)$ & \\
\cline { 2 - 3 } & Severe & $2(15.4 \%)$ & \\
\hline
\end{tabular}

The asphyxia was higher in home delivery $(85 \%)$ as compare to hospital delivery $(15 \%)$ which was statically significant $\mathrm{p}$ value $<0.05$.

Table-4: Evidence of birth injury among the asphyxiated newborn

\begin{tabular}{|l|l|l|}
\hline Type of injury & No of cases & Mortality \\
\hline Subgaleal hematoma & $46(50 \%)$ & $10(21.7 \%)$ \\
\hline Abrasion /contusion & $27(30 \%)$ & $2(7.4 \%)$ \\
\hline Cephalohematoma & $12(13 \%)$ & $3(25.2 \%)$ \\
\hline Fracture & $8(7 \%)$ & $5(62.5 \%)$ \\
\hline Total & 93 & 23 \\
\hline
\end{tabular}

Out of 151 patient 93 patients $61.5 \%$ were having birth injury \& mortality was maximum (62.5\%) in babies having fractures skull. 
Table-5: Time of onset of convusion

\begin{tabular}{|l|l|l|}
\hline Time of onset & No of cases & Percentage \\
\hline $0-12$ hours & 17 & 32 \\
\hline $13-24$ hours & 25 & 42 \\
\hline $25-48$ hours & 9 & 16 \\
\hline $49-72$ hours & 2 & 3.7 \\
\hline $73-120$ hours & 1 & 2 \\
\hline
\end{tabular}

The above table shows that the convulsion was maximum (42\%) within 24 hours of birth \& was minimum (2\%) after 72 hours of birth.

Table -6: Pattern of muscle tones in asphyxiated babies

\begin{tabular}{|l|l|l|l|l|}
\hline Tone & Cases & Percentage & Mortality & Percentage \\
\hline Normal & 73 & 48.3 & 0 & 0 \\
\hline Hypertonia & 44 & 29.4 & 3 & 6.8 \\
\hline Hypotonia & 20 & 12.7 & 8 & 40 \\
\hline Severe hypotonia & 14 & 9.2 & 12 & 85.7 \\
\hline
\end{tabular}

The maximum asphyxiated babies having normal muscle tone $(48.3 \%)$. Mortality is highest $(85.7 \%)$ in babies having severe hypotonia.

Table-7: Incidence of complications of birth asphyxia

\begin{tabular}{|l|l|l|}
\hline Complications & No of birth asphyxia & Percentage \\
\hline Apnoea & 34 & 22.5 \\
\hline Respiratory distress & 80 & 52.9 \\
\hline Hypoglycaemia & 26 & 17.2 \\
\hline Neurological abnormality & 74 & 49 \\
\hline Sepsis & 71 & 47 \\
\hline Neonatal jaundice & 73 & 48.3 \\
\hline Renal failure & 44 & 29.1 \\
\hline Coagulopathy & 19 & 12.5 \\
\hline
\end{tabular}

Respiratory distress was maximum (52.9\%) in asphyxiated babies followed by neurological abnormality $49 \%$ followed by neonatal jaundice.

Table-8: Distribution of age of death

\begin{tabular}{|l|l|l|}
\hline Day & No of death & \% of death \\
\hline$<1$ & 3 & 13 \\
\hline $1-3$ & 11 & 43.4 \\
\hline $4-7$ & 4 & 17.3 \\
\hline$>7$ & 5 & 21.7 \\
\hline
\end{tabular}

The mortality was $15.23 \%$ and maximum death occurred within 1 to 3 days of life $(43.4 \%)$ \&minimum within 4 to 7 days.

FOLLOW UP: of 151 infants 23 (11 in stage III, 7 in stage II, and 5 in stage I) died in the hospital. 60 babies (40 in stage I, 20 in stage II) were eventually discharged. Now out of 68 infants 4 from HIE III group died at home due to respiratory distress. 4 from HIE II group lost to follow up. 30 babies from HIE -I group did not came for follow up. Thus only 30 cases could be available for follow up study. Out of them 8 were in stage III, 10 were in stage II, 12 in stage I. Developmental mile stones appropriate for age was asked for and infants evaluated for developmental delay.

Table -9: Relationship of development delay with hie

\begin{tabular}{|l|l|l|l|l|}
\hline $\begin{array}{l}\text { Stage of } \\
\text { HIE }\end{array}$ & $\begin{array}{l}\text { No of } \\
\text { cases }\end{array}$ & $\begin{array}{l}\text { Normal developmental } \\
\text { milestone }\end{array}$ & $\begin{array}{l}\text { Abnormal developmental } \\
\text { mile stone }\end{array}$ & $\begin{array}{l}\text { Percentage of } \\
\text { abnormality }\end{array}$ \\
\hline I & 21 & 20 & 1 & 3.3 \\
\hline II & 5 & 2 & 3 & 60 \\
\hline III & 4 & 0 & 4 & 100 \\
\hline
\end{tabular}


All babies suffered from HIE-III had delayed developmental mile stone.

Table-10: Relationship with neurological deficit

\begin{tabular}{|l|l|l|l|l|l|l|l|}
\hline $\begin{array}{l}\text { Stage } \\
\text { of HIE }\end{array}$ & $\begin{array}{l}\text { No of } \\
\text { cases }\end{array}$ & $\begin{array}{l}\text { Neurological } \\
\text { deficit }\end{array}$ & $\begin{array}{l}\text { Abnormal } \\
\text { BERA }\end{array}$ & $\begin{array}{l}\text { Abnormal } \\
\text { EEG }\end{array}$ & $\begin{array}{l}\text { Cranial } \\
\text { ultrasound }\end{array}$ & $\begin{array}{l}\text { Brain } \\
\text { MRI }\end{array}$ & $\begin{array}{l}\text { Developed } \\
\text { Cerebal Palsy }\end{array}$ \\
\hline I & 12 & 0 & 0 & 0 & 0 & 0 & 0 \\
\hline II & 10 & 3 & 2 & 0 & 2 & 1 & 1 \\
\hline III & 8 & 8 & 3 & 8 & 8 & 8 & 8 \\
\hline
\end{tabular}

All babies suffered from HIE-III were having neurological deficit, abnormal BERA, abnormal EEG, cranial ultra sound showing peri-ventricular leucomalacia which is confirmed by MRI.

Table-11: Head circumference of babies at follow up.
\begin{tabular}{|l|l|l|}
\hline \multirow{2}{*}{ Stage of HIE } & \multicolumn{2}{|c|}{ Head circumference } \\
\cline { 2 - 3 } & Normal for age & Small for age \\
\hline I & 11 & 1 \\
\hline II & 7 & 3 \\
\hline III & Nil & 8 \\
\hline
\end{tabular}

All babies suffered from HIE-III were having small for age head circumference.

Table-12: Nutritional status of the babies

\begin{tabular}{|l|l|l|l|l|}
\hline Stage of HIE & No of cases & Normal Nutritional status & Below normal & Percentage \\
\hline I & 12 & 8 & 4 & 30 \\
\hline II & 10 & 2 & 8 & 75 \\
\hline III & 8 & Nil & 8 & 100 \\
\hline
\end{tabular}

All babies suffered from HIE-III were having below normal nutritional status.

\section{DISCUSSION}

The overall incidence of birth asphyxia in S C B Medical college was 4.6 per 1000 life birth (There was 14,578 live birth during the study period, out of which 672 were asphyxiated). The incidence of asphyxia neonatorum in the present series is close to the finding of Kapoor et al. [16] at $6.3 \%$ and William McGuire et al. [24] at 5-10/1000 live birth. 1 to 6 per 1000 live full term births was found by de Haan $M$ et al. [25] \& Levene et al. [26]. The different grade of asphyxia in our study was HIE -I 57.6\%, HIE-II $27.15 \%$, HIE -III $15.23 \%$ which is different from study done by Caroline et al. [27] who found it 39\%,39\% and $22 \%$ respectively. Difference may be due to availability of care at birth.

Death due to birth asphyxia in our study was 15.23\%. Anne CC Lee et al. [28] found that Birth asphyxia deaths (9.7/1,000 live births) accounted for $30 \%$ of neonatal mortality, which is as per with our result. Lawn JE et al found $23 \%$ of neonatal morbidity and mortality is birth asphyxia [2] of 41 in HIE-II, 7 died moratlity being $17.07 \%$. Levene et al. [26] reported very low mortality in this group $(4.34 \%)$.

Mode of delivery as an important predisposing factor in asphyxia neonatorum was quite obvious in the present study only $23.1 \%$ of the new born delivered by LSCS, the incidence among the vaginal delivery was $70.8 \%$. The present study corroborates with the study of Kapoor et al. [16] who reported higher incidence of neonatal asphyxia in vaginal delivery. Dweck et al. [29] reported $60 \%$ asphyxiated babies born out of abnormal labour and delivery. The present results are somewhat at variance to the finding of Gupta et al. [30] who reported the risk of asphyxia to be 18 times more in babies born by LSCS. This may be due to delivery by untrained personnel from rural catchment area.

The babies who had HIE in the present study were grouped into 3 grades of severity according to Sarnat's clinical staging. $57.6 \%$ were in mid encephalopathy (HIE-I), $27.1 \%$ in the moderate encephalopathy (HIE-II) and $15.2 \%$ in severe encephalopathy (HIE-II). Swati Mondal et al. [31] found Majority of study infants suffered mild Hypoxic ischemic enchephalopathy (59\%) whereas moderate and severe HIE sufferers were $31 \%$ and $10 \%$ respectively in the study population, which is similar to our study.

The incidence of convulsion was noted in 54 patients $(35.7 \%)$. This observation is in accordance with the report of Volpe [32] and Alfred W. Brann jr[33].

The mortality was $15.23 \%$ and maximum death occurred within 1 to 3 days of life $(43.4 \%) \&$ minimum within 4 to 7 days. Anne CC Lee et al[28] found that median age at death due to birth asphyxia was 11 hours; $158(69 \%)$ and $228(99 \%)$ of such deaths occurred within the first 1 and 7 days of life, respectively which is more than our study. 
Various type of muscle tone abnormalities were noticed of which normal flexor tone had best prognosis and severe hypotonia has the worst. Similar observations have been made by Brown et al [34] and De souza [35] who found that the abnormality of the tone is an important predictor of death. $48.3 \%$ of asphyxiated babies had normal flexor tone. Mortality in this group is nil. $29.4 \%$ had hypertonia and mortality in this group is was $6.8 \% .12 .74 \%$ babies had hypotonia and mortality was $40 \%$. Severe hypotonia was present in $9 \%$ of the babies and was associated with $85.7 \%$ mortality.

Two percent (3/149) of asphyxiated neonates had abnormal OAEs as studied by Elaheh et al [36]. BERA confirmed hearing loss due to hypoxic brain damage in only 1 infant as reported by Swati et al [31]. Our study also reported similar result i.e. No significant association was found between HIE and hearing loss.

E E G finding were normal in HIE - I. EEG is abnormal in almost all case of HIE-III, which is similar to the study done by Hatem et al. [37]

Cranial ultra sound finding was abnormal in HIE-III, which is similar to the study done by Malick et al. [38] \& Ny Boo et al. [39] Poornima Shankar et $\operatorname{al}[40]$.

Abnormality in brain MRI detected by our study is as similar to the study done by Ernst Martin et al [41] and Wei Shen et al. [42]

Lindström K et al. [43] found $30 \%$ of perinatal asphyxia developed cerebral palsy which is nearly similar to our study $26.66 \%$.

Head circumference was small for age in $10 \%$ of HIE-I, $25 \%$ of HIE-II, $100 \%$ in HIE-III.

Growth (gain in length and weight) was poor in $30 \%$ in HIE-I, $75 \%$ in HIE-II, 100\% in HIE-III.

The incidence if sepsis was found in $47 \%$ cases, hypoglycaemia in $17.2 \%$ cases, renal failure in $21.9 \%$ cases. In the present study encephalopathy constitutes $55.6 \%$ and respiratory abnormality in $52.9 \%$ followed by neonatal jaundice in $48.3 \%$ and sepsis in $47 \%$.

Maximum (43.3\%) neonatal death due to perinatal asphyxia occurred within 3days which is similar to the study done by Chowdhury HR et al. [44] and Abayneh G et al. [45].

\section{SUMMARY}

Incidence of asphyxia among the normal delivered babies was very high as compared to the babies of LSCS. Severity of asphyxia was high in face presentation, followed by breech than normal delivery. Respiratory distress was found to be associated neonatal asphyxia in this study. Most of the neonatal death in this present study occurred in first 3days of life because of perinatal asphyxia. In follow up study developmental delay was found to be $5 \%$ in HIE -I, 50\% in HIE-II and $100 \%$ in HIE-III. Neurological deficit in these group were $0 \%$ in HIE-I, $25 \%$ in HIE-II, $100 \%$ in HIE-III. Convulsion was present in asphyxiated babies and maximum convulsion occurred within 24hours. The pattern of muscle tone was good predictor of prognosis. Normal flexor tone was associated with good prognosis. Hypertonia was found to be associated with a poor prognosis. Whereas hypotonia had worse prognosis. Severe hypotonia have grave prognosis. Majority of the infants had mild encephalopathy. Sarnat's stage I encephalopathy was associated with good prognosis. Mortality was low and long term sequale were minimum. Infants with moderate encephalopathy (HIEII) had higher mortality but neurological sequeale among the survivors were not severe and developmental delay occurred fairly commonly. Severe HIE (stage-III) was associated with a grave prognosis. Mortality was very high. Survivors had gross developmental delay and severe neurological deficits. Poor growth pattern was noted in HIE -II and HIE-III.

\section{CONCLUSION}

Perinatal asphyxia may affect the newborn for few minutes of hypoxic episode but may have lifelong neurological consequences. HIE is preventable rather than treatable. Timely and corrective step taken during each and every step during the delivery process will definitely reduce the incidence of perinatal asphyxia, also reduces the burdens of mortality and morbidity.

What the study add: Perinatal asphyxia- a major cause of mortality and morbidity in developing country like India, need timely and corrective step during each and every step during the delivery process.

\section{REFERENCES}

1. National neonatal forum. National neonatal perinatal database. Report for the year; 2010.

2. Lawn JE, Cousens S, Zupan J. Lancet Neonatal Survival Steering Team. 4 million neonatal deaths: When? Where? Why? Lancet. 2005; 365:891-900.

3. Lawn J, Shibuya K, Stein C. No cry at birth: Global estimates of intrapartum stillbirths and intrapartumrelated neonatal deaths. Bull World Health Organ. 2005; 83:409-417.

4. Stanton C, Lawn JE, Rahman H, WilczynskaKetende K, Hill K. Stillbirth rates: Delivering estimates in 190 countries. Lancet. 2006; 367:1487-1494.

5. World Health Organization. World Health Report. WHO; Geneva: 2005. [Accessed 3/1/2007]. 2005; 2005.

6. World Health Organization. Basic Newborn Resuscitation: A Practical Guide. World Health Organization; Geneva: 1997. 
7. Committee on Fetus and Newborn. American Academy of Pediatrics. Committee on Obstetric Practice. American College of Obstetricians and Gynecologists Use and abuse of the Apgar score. Pediatrics. 1996; 98:141-142.

8. Lawn JE, Manandar A, Haws R, Darmstadt GL. Reducing one million child deaths from birth asphyxia -- policy and programme gaps and priorities based on an international survey. Health Res Policy Systems. 2007;5:4.

9. Bang AT, Bang RA, Baitule SB, Reddy HM, Deshmukh MD. Management of birth asphyxia in home deliveries in rural Gadchiroli: The effect of two types of birth attendants and of resuscitating with mouth-to-mouth, tube-mask or bag-mask. J Perinatol. 2005;25(Suppl 1):S82-91.

10. Haider BA, Bhutta ZA. Birth asphyxia in developing countries: current status and public health implications. Current problems in pediatric and adolescent health care. 2006;5(36):178-88.

11. Hankins GD, Speer M. Defining the pathogenesis and pathophysiology of neonatal encephalopathy and cerebral palsy. Obstetrics \& Gynecology. 2003 Sep 1;102(3):628-36.

12. Syalfina AD, Devy SR. Analysis Risk Factors of Asphyxia Neonatorum. Jurnal Berkala Epidemiologi. 2015 Sep 1;3(3):265-76.

13. National neonatal forum. National neonatal perinatal database. Report for the year; 2003

14. Thora S, Amadhiya A, Chansoria A, Kaul KK. Perinatal and infant mortality in urban slums under ICDS Scheme.Indian Pediatr. 1986; 23: 595-598.

15. Nita Bhandari, Rajiv Bahl, Sunita Taneja, Jose Martines, Maharaj K Bhan Pathways to Infant Mortality in Urban Slums of Delhi, India: Implications for Improving the Quality of Community- And Hospital-Based Programmes J Health Popul Nutr. 2002 Jun;20(2):148-55.

16. Kapoor RK, Srivastava AK, Misra PK, Sharma B, Thakur S, Srivastava KL, Singh GK. Perinatal mortality in urban slums in Lucknow. Indian pediatrics. 1996 Jan 1;33:19-24.

17. Nelson KB, Leviton A. How much of neonatal encephalopathy is due to birth asphyxia?. American journal of diseases of children. 1991 Nov 1;145(11):1325-31.

18. Sarnat HB, Sarnat MS. Neonatal encephalopathy following fetal distress. A clinical and electroencephalographic study. Arch Neurol. 1976;33:696-705.

19. Kliegman RM, Stanton B, St. Geme JW III, Schor NF, Behrman RE, editors. Nelson textbook of pediatrics. 19th ed. Philadelphia: Elsevier Saunders; 2011.

20. Black RE, Cousens S, Johnson HL, Lawn JE, Rudan I, Bassani DG, Jha P, Campbell H, Walker CF, Cibulskis R, Eisele T. Global, regional, and national causes of child mortality in 2008: a systematic analysis. The lancet. 2010 Jun 5;375(9730):1969-87.
21. Young Infants Clinical Signs Study Group. Clinical signs that predict severe illness in children under age 2 months: a multicentre study. The Lancet. 2008 Jan 12;371(9607):135-42.

22. William Lefkowitz Oxygen and Resuscitation: Beyond the Myth Pediatrics. 2002 Mar;109(3):5179. doi: 10.1542/peds.109.3.517

23. Tin W, Wariyar U. Giving small baby's oxygen: 50 years of uncertainty. Semin Neonatol. 20027361-367.

24. William McGuire, Perinatal asphyxia, BMJ Clin Evid. 2007: 0320.

25. Michelle De Haan John S. Wyatt Simon Roth Faraneh Vargha-Khadem David Gadian Mortimer Mishkin Brain and cognitive-behavioural development after asphyxia at term birth. https://doi.org/10.1111/j.1467-7687.2006.00499.x

26. Levene ML, Kornberg J, Williams TH. The incidence and severity of post-asphyxial encephalopathy in full-term infants. Early Hum Dev. 1985; 11:21-26.

27. Ahearne CE, Boylan GB, Murray DM. Short and long term prognosis in perinatal asphyxia: An update. World J Clin Pediatr. 2016; 5(1): 67-74 Available from: URL: http://www.wjgnet.com/2219-2808/full/ v5/i1/67.htm

DOI: http://dx.doi.org/10.5409/wjcp.v5.i1.67

28. Lee AC, Mullany LC, Tielsch JM, Katz J, Khatry SK, LeClerq SC, Adhikari RK, Shrestha SR, Darmstadt GL. Risk factors for neonatal mortality due to birth asphyxia in southern Nepal: a prospective, community-based cohort study. Pediatrics. 2008 May 1;121(5):e1381-90.

29. Dweck HS, Huggins W, Dorman LP, Saxon SA, Benton Jr JW, Cassady G. Developmental sequelae in infants having suffered severe perinatal asphyxia. American journal of obstetrics and gynecology. 1974 Jul 15;119(6):811-5.

30. Gupta S, Sinha SK, Tin W, Donn SM. A randomized controlled trial of post-extubation bubble continuous positive airway pressure versus Infant Flow Driver continuous positive airway pressure in preterm infants with respiratory distress syndrome. The Journal of pediatrics. 2009 May 1;154(5):645-50.

31. Swati Mondal. "A Study on Hearing Screening Among Patients with Neonatal Asphyxia in a Rural Tertiary Care Hospital." IOSR Journal of Pharmacy (IOSRPHR).2020; 10(4): 01-04.

32. Volpe JJ. Neonatal encephalopathy: an inadequate term for hypoxic-ischemic encephalopathy. Ann Neurol. 2012;72:156-166.

33. Alfred W. BrannJr. Pediatric Clinics of North America. 1986; 33(3): 451-464

34. Brown JK, Purvis RJ, Forfar JO, Cockburn F. Neurological aspects of perinatal asphyxia. Dev Med Child Neurol. 1974 Oct;16(5):567-580. 
35. De Souza SW, Richards B. Neurological sequelae in newborn babies after perinatal asphyxia. Arch Dis Child. 1978 Jul;53(7):564-569.

36. Amini E, Farahani ZK, Samani MR, Hamedi H, Zamani A, Yazdi AK, Nayeri F, Nili F, Rezaeizadeh G. Assessment of Hearing Loss by OAE in Asphyxiated Newborns. Iranian Red Crescent Medical Journal. 2014 Jan;16(1).

37. Elshorbagy HH, Azab AA, Kamal NM, Barseem NF, Bassiouny MM, Elsayed MA, Elkhouly TH. Value of electroencephalographic monitoring in newborns with hypoxic-ischemic encephalopathy treated with hypothermia. Journal of pediatric neurosciences. 2016 Oct;11(4):309.

38. Malick BL, Murmu MC, Mohanty AK. Study of cranial ultrasound finding in hypoxic ischemic encephalopathy in term infants and its clinical corelation.

39. Ny Boo V Chandran Ma Zulfiqar Sm Zamratol Mk Nyein Ms Haliza Ms Lye Early cranial ultrasound changes as predictors of outcome during first year of life in term infants with perinatal asphyxia https://doi.org/10.1046/j.14401754.2000.00518.x

40. Shankar P, Nithya SL. Role of cranial ultrasound in high risk neonates in NICU. Journal of Evolution of Medical and Dental Sciences. 2014 Apr 14;3(15):3970-7.
41. Martin E, Barkovich AJ. Magnetic resonance imaging in perinatal asphyxia. Archives of disease in childhood. Fetal and neonatal edition. 1995 Jan;72(1):F62.

42. Shen W, Pan JH, Chen WD. Comparison of transcranial ultrasound and cranial MRI in evaluations of brain injuries from neonatal asphyxia. International journal of clinical and experimental medicine. 2015;8(10):18319.

43. Lindström K, Hallberg B, Blennow M, Wolff K, Fernell E, Westgren M. Moderate neonatal encephalopathy: Pre-and perinatal risk factors and long-term outcome. Acta obstetricia et gynecologica Scandinavica. 2008 May;87(5):5039.

44. Chowdhury HR, Thompson S, Ali M, Alam N, Yunus M, Streatfield PK. Causes of neonatal deaths in a rural subdistrict of Bangladesh: implications for intervention. J Health Popul Nutr. 2010;28(4):375-382

45. Abayneh Girma Demisse, Fentahun Alemu, Mahlet Abayneh Gizaw, and Zemene Tigabu Patterns of admission and factors associated with neonatal mortality among neonates admitted to the neonatal intensive care unit of University of Gondar Hospital, Northwest Ethiopia Pediatric Health Med Ther. 2017; 8: 57-64. (5.97). 